\title{
El Myudhorib
}

Jurnal Kajian Ekonomi dan Perbankan Syariah

Volume 2 Nomor 1 Juni 2021

E-ISSN: $2722-5615$

http://e-journal.iainfmpapua.ac.id/index.php/elmudhorib

\section{DAMPAK CORONA VIRUS DILIHAT DARI PEMBIAYAAN DAN DPK PADA BANK SYARIAH MANDIRI}

\author{
Rindy Valentini \\ Universitas Islam Negeri Raden Intan Lampung \\ Email : valentini.rindy14@gmail.com \\ Muhammad Iqbal Fasa \\ Universitas Islam Negeri Raden Intan Lampung \\ Email :miqbalfasa@radenintan.ac.id

\section{Suharto} \\ Universitas Islam Negeri Raden Intan Lampung \\ Email : Prof.suharto@radenintan.ac.id
}

Received:

April 26, 2021

1st Revision:

July 04, 2021

Published:

July 25, 2021

\begin{abstract}
in Indonesia the emergence of the corona virus in March 2020 until now, the Corona Virus has a huge impact on global economic growth. Corona virus can reduce the business world, seen from banking financial institutions. Research was made to identify the effects of covid-19 on Bank Mandiri Syariah. This research is a type of qualitative research with a naturalistic approach because this research is in a natural state. The discussion is with a descriptive approach. Based on the results of research conducted showing all the impacts of the Corona Virus on the role of banks as intermediaries, sourced from the BSM financial report, it can be seen that there are fluctuations in financing and deposits BSM financing from January to March 2020 has increased. It can be seen from the fluctuation of DPK in BSM. As a result of the corona virus on the banking operational strategy. Based on the results of research at BSM, it shows that if all banks carry out economic actions regarding the restructuring of financing for customers affected by the Corona Virus pandemic, the source is POJK Number. 11 / POJK. 03/2020. Second, developing the use of the M-banking application in Islamic banks.
\end{abstract}

Keywords: Covid-19, Perbankan Syariah, Strategic Management 


\begin{abstract}
Abstrak
Di Indonesia munculnya corona virus pada bulan maret 2020 sampai pada saat ini, virus corona sangat berdampak terhadap pertumbuhan ekonomi secara global.Corona virus dapat menurunkan dunia usaha,dilihat dari lembaga keuangan perbankan. Riset dibuat untuk mengenali akibat covid19 terhadap Bank Mandiri Syariah ini. Riset ini ialah tipe riset kualitatif dengan pendekatan naturalistik sebab riset ini pada dalam keadaan alamiah. Pembahasannya dengan Pendekatan deskriptif. Berdasarkan hasil riset yang dilakukan menampilkan semua dampak Virus Corona terhadap peran perbankan sebagai intermediasi, bersumber dari Laporan keuangan BSM dapat dilihat Pembiayaan dan DPK adanya fluktuasi. Pembiayaan BSM pada bulan Januari hingga bulan Maret 2020 mengalami peningkatan.Dilihat dari DPK pada BSM mengalami fluktuasi. Akibat corona virus terhadap strategi operasional perbankan. Bersumber pada hasil riset di BSM menunjukkan apabila seluruh bank menjalankan tindakan ekonomi tentang penataan kembali pembiayaan untuk nasabah yang terserang pandemi Corona Virus bersumber pada POJK Nomor. 11/ POJK. 03/ 2020. Kedua, mengembangkan penggunakan aplikasi M-banking pada bank syariah.
\end{abstract}

Kata Kunci: Covid-19, Bank Syariah Mandiri, Manajemen Strategi

\title{
1. PENDAHULUAN
}

Fenomena yang dialami oleh seluruh dunia saat ini adalah pandemic covid-19, terjadi di seluruh dunia yang mempunyai dampak buruk pada ekonomi di setiap Negara. Sekian banyak lembaga telah menduga lemahnya perekonomi secara global seperti IMF (International Monetary Fund) yang memandang perkembang negative memasuki angka 3\% secara keseluruhan(Thaha, 2020: 148).

Pandemi ini sudah berlangsung dibeberapa Negara yang berakibat secara signifikan. Tidak hanya Cina,Korea Selatan mengalami dampak terhadap ekonomi.Negeri Gingseng, yang mempunyai perkembangan ekonomi semulanya diproyeksikan berkembang pada kuartal I dengan angka 2, 1\% tetapi adanya penyusutan $0,4 \%$.Negeri Thailand serta Taiwan juga di perkirakan terjadi perkembangan ekonomi terendah dalam separuh decade yang menggapai angka $0,2 \%$ serta 1,3\% di kuartal saat ini. Direktur world bank menafsirkan perekonomi Negara Indonesia diperkirakan mulai melemah dibawah 5\% pada kuartal I- 2020 (Yamali \& Putri, 2020: 386).

Komisi Kesehatan Nasional Tiongkok per Selasa, 11 Februari 2020, memberikan informasi tentang korban Covid-19 di Tiongkok daratan telah menggapai angka 1.016. Ada bermacammacam permasalahan baru yang terlihat terus terus meningkat pada saat ini. Korban wafat akibat virus corona ini berjumlah lebih banyak dari korban wafat akibat wabah SARS (Severe Acute Respiratory Syndrome) pada 2003 di Provinsi Guangdong, SARS dengan kilat menyebar ke seluruh dunia serta menewaskan 800 orang.Tiongkok pada tahun 2003 merupakan Negara dengan perekonomian terbanyak ke-6 di dunia. Tetapi pada saat ini Tiongkok merupakan negeri dengan perekonomian terbanyak kedua di dunia sehabis Amerika Serikat. Perekonomian yang sangat luar biasa sebesar $0,5 \%$ sampai $1 \%$ pasti.Donasi Tiongkok pada saat SARS menyerang perekonomian dunia kurang dari 2 persen (Burhanuddin \& Abdi, 2020:96). 
Dikeluarkanlah sebuah UU No 21 tahun 2020 tentang social distancing dengan tujuan untuk mengurangi kegiatan orang untuk face to face serta barang dan mewajibkan masyarakat untuk Work from Home(WFH).Kebijakan sudah dilakukan oleh pemerintah dalam mengurangi dampak Virus Corona yang bekembang secara meluas(Hardilawati, 2020: 90).Secara langsung terdapat kebijakan yang berakibat positive dan berakibat negative secara tidak langsung, perkembangan ekonomi di Indonesia sangat merosot pada saat ini. Di seluruh bidang perekonomian di Indonesia pandemic ini banyaknya menyebabkan karyawan yang di PHK, terbentuknya PMI Manufacturing Indonesia, penyusutan impor,terjalin pula kerugian pada sector pariwisata yang menimbulkan penyusutan okupansi,dan kenaikan harga ( inflasi) (Yamali \& Putri, 2020: 387).

Perbakan syariah sebagai lembaga intermediasi merupakan alat untuk keuangan yang mempertemukan antara 2 jenis pihak yaitu orang yang mempunyai kelebihan uang dengan orang yang mempunyai kekurangan uang untuk bisa berhubungan dengan kehidupannya, tetapi Covid19 memiliki ancaman berupa tantangan untuk lembaga keuangan yaitu Perbankan (Sumadi, 2020,147). Perkembangan ekonomi dunia pada saat pandemic berdampak secara signifikan. dunia bisnis memiliki tantangan pada saat pandemi terutama lembaga keuangan khususnya perbankan syariah.(Ningsih \& Mahfudz, 202: 2).

Penelitian terhadap covid-19 terhadap Perbakan Syariah telah dilakukan oleh Sumadi(2020).Pada berbagai sector virus corona mempunyai pengaruh banyak khusunya sektor ekonomi (Abdi, 2020: 2).dan memicu penulis melakukan penelitian yang bertujuan untuk melanjutkan penelitian sebelumnya tentang dampak covid-19 terhadap BSM.di sini penulis melihat apakah covid-19 ini berpengaruh terhadap pembiayaan dan DPK yang dilakukan oleh BSM.

\section{KAJIAN LITERATUR}

\section{Pengertian Covid-19}

Penyebaran wabah dari suatu daerah menuju banyak daerah lain di segala dunia termasuk Indonesia yaitu Covid-19.Penyebaran Virus corona sangat cepat.keganasan penyakit tidak memiliki hubungannya dengan hal ini melainkan meluas penyebaran virus yang dilakukan secara cepat.Corona Virus termasuk virus yang langkah dan baru muncul setelah terjadi pada Desember 2019 tepatnya di Wuhan Cina. WHO( disebut Organisasi Kesehatan Dunia secara formal melaporkan virus selaku pandemi yang terjadi pada 9 Maret 2020. Virus Corona ialah jenis penyakit meluas yang disebabkan oleh terinfesinya virus pada seseorang. COVID- 19 memiliki tanda-tanda pada orang yang terinfeksinya yaitu terjadi penyakit respirasi ringan dan dapat sembuh tanpa butuh perawatan special.Biasannya orang yang sudah berumur dan memiliki penyakit bawaan seperti,kardiovaskular, diabet, gangguan respirasi kronis, serta kanker mudah terinfeksi oleh Virus Corona ini. Penyebar Covid-19 melalui media secara langsung ataupun kontak tidak langsung seperti melalui media yang terkena cairan dari hidung ataupun air liur orang yang terserang Flu.banyak orang harus dilindungi dengan baik agar tidak terkena Virus Corona( World Health Organization, 2020b)(Hafizd, 2020: 140).

\section{Pengertian Perbankan Syariah}


Pada perbankan syariah ataupun perbankan konvensional terjadi aktifitas yang berkaitan dengan keyakinan Nasabahnya. Dalam operasinya bank lebih banyak memakai dana dari Nasabahnya dibandingkan dengan modal pemilik itu sendiri ataupun pemegang saham.hal ini karena dalam melaksanakan usahanya pengelola bank dituntut untuk menjaga likuiditas yang sesuai dengan pencapaian rentabilitas yang normal, dan modal yang tercukupi(Hijriyani \& Setiawan, 2017: 195). dalam muamalah pada bank syariah harus terhindar dari gharar( tidak jelas)harus terdindar dari kezaliman,yang paling penting bukan termasuk riba yang dapat menimbulkan haramnya harta(Mitra \& Bekasi, 2017: 44). dalam menghimpun serta menyalurkan dana warga perbankan nasional memiliki peran dengan pembiayaan yang prioritas terjadi pada koperasi,tanpa diskriminasi pada pengusaha kecil sehingga hendak menguatkan struktur ekonomi nasional. UU Nomor. 10 tahun 1998 tentang perbankan, baik universal ataupun BPR dicoba dengan metode konvensional ataupun bersumber pada sistem syariah tentang penyelengaraan operasional bank(Susila, 2017:134).

Transaksi- transaksi bisnis yang terjalin di Indonesia pada lembaga keuangan baik bank ataupun nonbank. Lembaga keuangan perbankan di Indonesia memakai dual banking system, yaitu perbankan yang memakai bunga dalam operasionalnya disebut dengan Bank Konvensional serta perbankan yang memakai prinsip- prinsip syariah dalam operasionalnya biasanya dikenal dengan Bank Syariah (Kholid, 2018: 146).

UU RI Nomor.21 Tahun 2008 tentang Perbankan Syariah Pasal 1 Poin 1, merupakan seluruh Unit Usaha syariah serta Bank Syariah menyangkut tentang Perbankan Syariah, mencankup kelembagaan,metode,dan aktivitas usahanya dalam melakukan usahanya (Nainggolan, 2021: 76).Kedudukan perbankan syariah yaitu mempunyai tujuan pembangunan nasional agar terciptanya kemakmuran pada setiap warganya,demokrasi ekonomi merupakan sumber yang berlandaskan kebersamaan, keadilan,serta berdasarkan dengan prinsip syariah(Bangsawan, 2017)

Perbankan syariah ialah salah satu lembaga keuangan yang berfungsi balancing, mengkoordinasikan serta mengkoordinasikan bermacam bidang perekonomian. Peran strategis dalam pembangunan adalah meningkatkan kualitas penghidupan warga negara secara keseluruhan melalui stabilitas nasional dan pertumbuhan ekonomi. Sedangkan bank adalah "Department of store", yaitu badan atau organisasi yang memberikan jasa atau jasa untuk berbagai jasa keuangan dimana aktivitas vitalnya adalah menerima pembayaran, tabungan, simpanan dan simpanan saat ini, yang digunakan untuk dapat melakukan kredit atau pinjaman uang yang ditujukan untuk setiap kebutuhan masyarakat, dan bank merupakan tempat yang digunakan dalam pertukaran uang(Ichsan et al., 2021: 298).

Dapat dilihat dari tahun ke tahun perkembangan industri perbankan dari jumlah bank, jumlah kantor, dan jumlah tenaga kerja semakin bertambah. Berdasarkan data yang dirilis oleh OJK yang menunjukkan hingga Desember 2019, jumlah BPRS di Indonesia mencapai 164 dengan jumlah kantor sebanyak 617 dan jumlah tenaga kerja sebanyak 6.620 orang(Syariah et al., 2020: 115).

\section{METODE PENELITIAN}

Riset ini berdasarkan Metode Kualitatif dengan pendekatan deskriptif, metode Kualitatif merupakan suatu metode yang berbentuk perkata yang diolah memakai secara deskripsi.(Alfianika, 2018: 22). Sebaliknya, pendekatan deskriptif ialah riset yang berupaya mendeskripsikan sesuatu kejadian, peristiwa,dan gejala yang sedang terjadi (E. Syariah et al., 
2020: 117). Objek Riset Ini merupakan Bank Mandiri Syariah,dan memakai teknik purposive sampling. metode yang merupakan opsi yang disengaja dari partisipan sebab mutu yang dipunyai partisipan yaitu Metode purposive sampling atau yang biasa dikenal dengan judgement sampling. Ini merupakan metode acak pada beberapa partisipan berupa bersumber pada pengetahuan ataupun pengalamany yang akan diteliti (Etikan, 2016).

\section{HASIL PENELITIAN DAN PEMBAHASAN Perkembangan Covid-19}

Dua orang warga Depok Jawa Barat tepatnya pada tanggal 2 maret 2020 terdapa orang yang terkonfirmasi terkena Covid-19, dikarenakan setelah melakukan kontak langsung dengan seorang warga Negara asing Asal jepang yang tinggal di Malaysia ternyata seorang penderita Covid-19 pada acara yang diselenggarakan di Jakarta. Penderita mengeluhkan demam, batuk serta sesak nafas setelah pertemuan tersebut. Dalam upaya penangkalan serta pengendalian wabah Covid- 19 di Indonesia sempat, kebijakan lockdown yang berupa karantina daerah, di terapkannya kebijakan social distacing ataupun physical distancing serta pembatasan sosial berskala besar (PSBB). Mula-mula berlaku di DKI Jakarta, setelah itu dikuti oleh Jawa Barat, Banten, Jawa Tengah serta Jawa Timur dan mulai berlaku di seluruh daerah Indonesia sampai dengan daerah terpencil.(Junaedi \& Salistia, 2020:111). Work From Home( WFH) dibuat karena sangat berpengaruhnya Virus Corona, Maka WFH ini di buat untuk mengurangi penyebaran Covid- 19 melalui pembatasan Social Distancing ataupun Physical Distancing sampai diterapkan PSBB adanya penurunan kegiatan ekonomi secara totalitas dikarenakan gerakan tersebut. Diterapkannya Work From Home ( WFH) menyebabkan adanya perubahan mobilitas di Indonesia (Tahliani, 2020: 94-95).

Pandemi ini menyebabkan dampak secara signifikan di seluruh dunia. Tidak hanya Cina, Negeri Korea Selatan pula berdampak pada perekonomian.Perkembangan ekonomi Negeri Gingseng, yang diperkirakan berkembang pada kuartal I dengan angka 2, 1\% hendak hadapi penyusutan dekat $0,4 \%$.Perekonomi Negeri Thailand serta Taiwan di perkirakan berkembang terendah dalam hampir separuh decade yang menduduki angka $0,2 \%$ serta 1,3\% pada kuartal saat ini.Prediksikan ekonomi Indonesia yang dilakukan oleh direktur Bank Dunia diperkirakan hendak melemah di bawah 5\% pada kuartal I- 2020. Covid- 19 yang terjadi pada tahun 2020 berdampak yang sangat besar untuk seluruhIndonesia. Berbagai macam dampak negatif pada saat wabah virus Corona ini yang berpengaruh di berbagai bidang perekonomian seluruh wilayah Indonesia. Setelah terjadinya perkembang Virus Corona yang sangat cepat ini, pemerintah memberlakukan PSBB untuk mengurangi Virus Corona yang terdapat dalam Peraturan Pemerintah Nomor 21 Tahun 2020. Dengan adanya Pembatasan Sosial Bersekalah Besar atau PSBB seluruh aktivitas yang biasa dicoba terpaksa terhenti sementara waktu. Segala aktivitas dibidang perkantoran ataupun Industri untukt semntara waktu terpaksa menyudahi untuk beroperasi. Tidak hanya itu, sector pembelajaran,segala tempat beribadah, Market place (pusat perbelanjaan), tempat pariwisata ,tempat makan,tempat sekolah pula hadapi perihal yang sama (Yamali \& Putri, 2020: 386).

Belum lama ini di Indonesia banyak kasus Covid-19 yang menimbulkannya banyak kerugian yang berakibat untuk Perekonomian Indonesia. Dasar pembangun ekonomi bertujuan agar tercapainya kemakmuran secara menyeluruh pada perkembangan ekonomi serta distribusi pemasukan. Hal ini tidak sama dengan kondisi Indonesia pada tahun 1997/ 1998 dimana krisis yang terjadi berawal dari krisis perbankan sampai menjalar menjadi krisis sosial serta politik di 
Indonesia yang sangat berdampak. Terdapat perkembangan laju inflasi yang menyebabkan turunnya daya beli warga, untuk seluruh kalangan terutama kalangan yang berpendapatan rendah, pergantian jumlah uang bisa pengaruhi tingkatan suku bunga, serta kegunaanya, jadi jumlah uang berpengaruh dalam permintaan Pada tahun 1998 terjadi krisis ekonomi yang sangat berbeda dengan keadaan saat sekarang ini dimana UMKM menjadi landasan di bidang perbankan yang berguguran karena dilikuidasi. Sedangkan dikala ini, UMKM jadi zona yang sangat berdampak dari akibat wabah Covid- 19. Hal ini disebabkan oleh menyusutnya nilai beli warga secara signifikan paling utama di tingkat terbawah (Sumarni, 2020: 50).

Covid 19 ini berakibat pada sebagian perbankan syariah yang harus diperbarui dalam menindak lanjutin penyebar berita-berita krisis akibat Covid- 19 pada perbankan yang menyebabkan munculah banyak resiko yang mungkin timbul. Pada proses berjalannya sistem perbankan adanya resiko dalam perkembangannya,pada dunia perbankan syariah. Sebagian resiko datang pada berbagai aspek yang terdapat resiko operasional yang bisa saja terjadi, terutamanya pada SDM selaku kontributor kinerja selaku dan aspek internal pada perbankan syariah ataupun pada nasabah selaku aspek eksternal perbankan syariah(Fauziah et al., 2020: 39-40).

\section{Strategi Perbankan syariah}

Pada masa Pandemi Covid- 19 terdapat berbagai macam akibat berkaitan dengan perekonomian Indonesia.ekspor Indonesia semenjak tahun 2011 pada Negara Cina sebagai informasi Pusat Statistik, diperkirakan tahun depan pencapaian 25,7 miliyar dollar AS dari nilai ekspor nonmigs Indonesia ke Cina. Sementara nilai ekspor nonmigas Indonesia ke Amerika Serikat serta ke Jepang jauh lebih besar dan memuduki peringkat kedua serta ketiga. Kegiatan impor Indonesia banyak diambil dari Negara Cina. Nilai impor Indonesia dari Cina pada tahun 2019 menggapai 44, 5 miliyar dollar AS,sama dengan 3 serta 5 mendekati setengah dibanding nilai impor Indonesia dari Jepang serta Amerika Serikat. penanaman modal asing di Indonesia yang terbanyak serta penyumbang lebih dari 2 juta turis asing ataupun dekat 12, 5 persen dari banyaknya turis asing yang datang ke Indonesia yaitu Negara Cina. (Yenti Sumarni, 2020:51). Perbankan syariah perlu adanya penyesuaian diri saat pandemi ini berlangsung di seluruh wilayah Indonesia, menyusun keadaan terbaru yang relevan dan sanggup menghadapi tiap tantangan perekenomian yang disebakan oleh Corona Virus. industri perbankan syariah memiliki tantangan awal agar dapat menjalankan cara bisnis dengan media digital pada layanan bank,yang diterapkan dalam pembiayaan termasuk juga penghimpunan dana. Kedua, untuk dapat survive di masa pandemi Covid- 19 perlunya pengurangan pembayaran Non Performing Finanacing ( NPF). Ketiga, mencari pilihan yang sesuai dengan market baru, minimun market yang tidak terdampak signifikan akibat pandemi Covid-19, sehingga di tengah maraknya pandemi Covid- 19 Perbankan Syariah masih bisa berdiri kokoh (Tahliani, 2020: 111).

Dalam menjaga menjaga stabilitas sistem keuangan pada perbankan, ancaman pelemahan ekonomi akibat pandemi covid-19. Selanjutnya, menerima akuisisi, Konsilidasi, merger, ataupun integrasi langkah yang dilakukan oleh OJK yaitu membagikan perintah kepada Bank untuk melaksanakan konsolidasi, pengambil alihan,merger,ataupun integrasi. Menurut POJK Nomor. 18/ POJK. 03/ 2020 Otoritas sepanjang PSBB mengeluarkan kebijakan tentang ( SP 26/

DHMS/ OJK/ IV/ 2020).Pembedahan Industri Jasa Keuangan pada Siaran Pers yang berlangsung sepanjang Periode Implementasi PSBB di berbagi Wilayah.OJK memohon kepada lembaga keuangan seperti perbankan agar mengurangi karyawan untuk menerapkan protokol 
kesehatan di tempat kerja. PSBB diwajibkan untuk seluruh lembaga keuangan agar diimplementasikan, serta mengurangi layanan dengan sistem Face to Face dan dapat menggantinya dengan layanan digital seperti m-banking.dan penerapan WFH atau berkerja dari rumah (Jannah, 2021)

Hasil riset adanya tantangan perbankan syariah dalam mengalami wabah tersebut merupakan peraturan usaha dengan mendigitalkan layanan pada perbankan, mendigitalkan penggalangan dana serta pembiayaan, serta meminimalkan pembayaran Non Performing Financing ( NPF) agar bertahan dari wabah Covid- 19, serta mencari pasar baru alternatif. Tidak sedikit usaha yang terkena wabah Covid- 19, disini bisnis yang dijalankan harus sesuai dengan protokol kesehatan, agar perbankan dapat kokoh di tengah wabah Covid- 19.

Menurut Habibah ( 2020) riset dengan data empiris ialah suasana yang didasarkan pada peristiwa nyata ataupun kejadian yang dirasakan. Bersumber pada temuannya secara universal, tantangan bank syariah dikala wabah Covid- 19 ialah likuiditas serta rasio NPF Pada Juli 2020 serta Agustus telah menciptakan tekanan di puncaknya perbankan. Efek yang dialami perbankan syariah pada wabah Covid-19 demikian pula penemuan Wahyudi ( 2020) yang mengatakan kalau kinerja perbankan syariah terkoreksi pada mulai munculnya wabah Covid- 19.

Riset yang dicoba oleh Mahfudz\&amp; Mardhiyaturrositaningsih (2020), analisis komparatif, bertujuan buat mengenali akibat wabah Covid- 19 terhadap strategi operasional manajemen Bank serta Aktivitas Intermediasi Bank dari segi perbankan syariah. Metode pengambilan ilustrasi memakai purposive sampling dengan pengolahan informasi sekunder dari 5 Bank Universal Syariah (BUS). Hasil riset menampilkan kalau dari akhir Desember sampai Maret 2020, segala lembaga keuangan hadapi fluktuasi pada guna DPK yang cenderung menyusut baik dari sisi pembiayaan ataupun penghimpunan dana. Bagi riset Fauziah et al.,( 2018) yang mempelajari tentang resiko operasional Islam bank sepanjang wabah Covid- 19 memakai desain riset kualitatif lewat pendekatan dengan permasalahan. Hasil riset menampilkan kalau bank syariah mengalami 2 tipe resiko sepanjang periode Covid-19 ini ialah ancaman eksternal serta internal. Resiko operasional internal merupakan bank butuh tingkatkan bayaran operasional semacam penyediaan hand sanitizer, tempat mencuci tangan, masker, desinfektan, dan lain-lain untuk menerapkan protokol kesehatan. Resiko operasional eksternal berasal dari penyusutan layanan kepada nasabah sebab terdapatnya syarat pembatasan nasabah yang tiba serta sterilisasi kantor cabang bank yang membatasi pelayanan. Oleh sebab itu, Perbankan Syariah butuh mulai merevisi strateginya, mengingat tidak terdapat satupun yang tahu pasti kapan Covid- 19 hendak berakhir. Memandang kasus tersebut, riset ini berupaya buat mengeksplorasi tantangan perbankan syariah sepanjang wabah Covid- 19 di Indonesia. Dengan demikian, sepanjang wabah Covid- 19 berfungsi sebagai pedoman dalam memutuskan strategi dalam memitigasi resiko di bank syariah (Azizah et al., 2020: 136).

\section{Bagaimana Dampak Covid-19 pada BSM}

Akibat aktivitas intermediasi pada Bank Syariah Mandiri .menampilkan pada Pembiayaan serta DPK pada Januari sampai Maret 2020 pembiayaan BSM meninggkat, tetapi DPK menampilkan fluktuatif. Hal ini menunjukkan kalau Pandemi Covid- 19 mejadi penghalang perbankan dalam Deposit Funds(DPK). Sementara,Financing(Pembiayaan) BSM berada pada tahap normal. Karena adanya Manajemen Strategi BSM yang berjalan dengan baik. 
Tabel . Financing dan Deposito Funds pada BSM

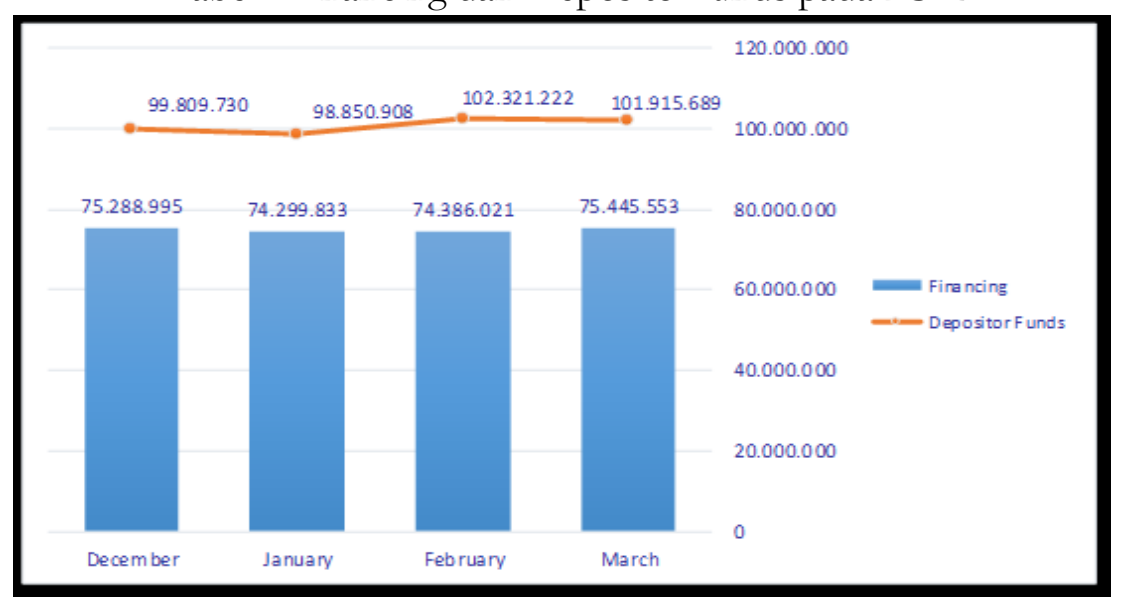

Sumber: Dampak Covid-19 pada BSM

Sepanjang pandemi Covid- 19 BSM menghasilkan keputusan tentang layanan serta produk yang menerapkan MSM (Mandiri Syariah Mobile). MSM sebagai Super aps tidak hanya sebagai aplikasi yang melaksanakan transaksi keuangan juga menawarkan berbagi macam bonus antara lain seperti fitur sedekah,mempermudah dalam pembayaran zakat dan wakaf,untuk beribadah serta memperoleh arah kiblat dengan mudah, jadwal sholat, juz amma, posisi masjid, kutipan hadits dan lain sebagainya. MSM bisa pula buat transaksi belanja melalui internet, top- up ewallet yang melupiti top-up seperti Ovo,e-money,gopay dan pembayaran dana haji. Kedua, Transaksi memakai smartphone atau biasa disebut dengan QRIS(Quick Response Code Indonesia Standard)dapat dilakukan lebih simpel dengan menggunakan gadget serta teknologi bmelaksanakan transaksi lewat tata cara pembayaran melalui digital QRIS. Ketiga, kebijakan Perekonomian Nasional Nomor. 11/ POJK. 03/ 2020. sarana yang dilakukan oleh bank berupa pembiayaan kepada nasabah diberikan kelonggaran karena terjadinya pandemi Covid- 19 seperti sekarang ini dalam wujud penyusutan margin serta penundaan pembayaran ataupun bagi hasil yang berlangsung dalam kurun waktu tertentu serta di sector ekonomi desesuaikan dengan kriteria, serta kondisi yang terjadi pada nasabah dengan senantiasa sesuai syarat ojk yang paling utama yaitu nasabah UMKM.(Ningsih \& Mahfudz, 2020).

\section{KESIMPULAN DAN SARAN}

Dampak Pandemi Covid-19 terhadap Dana Pihak ketiga pada Bank Mandiri Syriah dilihat dari fungsi intermediasi,adanya gejolak pada sisi pembiayaan BSM sepanjang bulan Januari sampai bulan Maret 2020 mengalami pertambahan atau peningkatan. Pada sisi, Deposito Funds (Penghimpunan Dana), BSM menunjukkan keadaan yang tidak tetap terjadinya naik atau turunnya yang biasa disebut dengan Fluktuatif. Karena manajemen strategi operasional perbankan memiliki dampak dari terjadinya Covid-19. Bersumber pada kesimpulan riset pada BSM menampilkan seluruh bank mempraktikkan kebijkan ekonomi untuk mengatasi krisis ekonomi pada perbankan syariah tentang pembiayaan yang dilakukan oleh perbankan syariah Nasabah Bank Mandiri syariah yang terkena dampak virus corona bersumber pada POJK Nomor. 11/ POJK. 03/ 2020. Kemudian yang Kedua yaitu BSM melakuakn Pengembangan aplikasi m-bankingnya. Riset ini memakai ilustrasi 
BUS yang biasanya dikenal dengan Bank Umum Syariah,keterbatasan informasi pada penelitian di BSM ini, diiharapkan untuk riset berikutnya bisa diteliti di seluruh BUS di Indonesia sehingga bisa lebih mendeskripsikan secara lebih umum lagi.

Riset tentang Dampak Covid-19 terhadap BSM ini masih banyak yang perlu diperbaharui dan dikembangkan,d iharapkan untuk penelitian selanjutnya disarankan meneliti Dampak Covid-19 pada Perbankan Syariah yang lain sehingga dapat menambah referensi penelitian,dan diharapkan penelitian mendatang dapat mememasukan variabel lain yang mumungkinkan untuk melihat Dampak Covid-19 terhadap Perbankan Syariah.

\section{DAFTAR REFERENSI}

Abdi, M. N. (2020). Krisis Ekonomi Global dari Dampak Penyebaran Virus Corona (Covid-19). AkMen Jurnal Ilmiah, 17(1), 90-98.

Alfianika, N. (2018). Buku ajar metode penelitian pengajaran bahasa Indonesia. Deepublish.

Azizah, N., Azhari, A. R., \& Wahyudi, R. (2020). Covid-19 outbreak : Islamic banking challenges in Indonesia. Islam in World Perspectives Symposium, 1(1), 134-141.

Bangsawan, M. I. (2017). Eksistensi Ekonomi Islam (Studi Tentang Perkembangan Perbankan Syariah Di Indonesia). Law and Justice, 2(1), 24-34. https://doi.org/10.23917/laj.v2i1.4334

Burhanuddin, C. I., \& Abdi, M. N. (2020). AkMen AkMen. Krisis, Ancaman Global, Ekonomi Dampak, Dari, 17, 710-718.

Etikan, I. (2016). Comparison of Convenience Sampling and Purposive Sampling. American Journal of Theoretical and Applied Statistics, 5(1), 1. https://doi.org/10.11648/j.ajtas.20160501.11

Fauziah, H. N., Fakhriyah, A. N., \& Rohman, A. (2020). Analisis Risiko Operasional Bank Syariah Pada Masa Pandemi Covid-19. Al-Intaj: Jurnal Ekonomi Dan Perbankan Syariah, 6(2), 38-45.

Hafizd, J. Z. (2020). Peran Bank Syariah Mandiri (Bsm) Bagi Perekonomian Indonesia Di Masa Pandemi Covid-19. Al-Mustashfa: Jurnal Penelitian Hukum Ekonomi Syariah, 5(2), 138. https://doi.org/10.24235/jm.v5i2.7402

Hardilawati, W. laura. (2020). Strategi Bertahan UMKM di Tengah Pandemi Covid-19. Jurnal Akuntansi Dan Ekonomika, 10(1), 89-98. https://doi.org/10.37859/jae.v10i1.1934

Hijriyani, N. Z., \& Setiawan, S. (2017). Analisis Profitabilitas Perbankan Syariah di Indonesia sebagai Dampak Dari Efisiensi Operasional. Jurnal Kajian Akuntansi, 1(2), 194-209. https://doi.org/10.33603/jka.v1i2.823

Ichsan, R. N., Suparmin, S., Yusuf, M., Ismal, R., \& Sitompul, S. (2021). Determinant of Sharia Bank's Financial Performance during the Covid-19 Pandemic. Budapest International Research and Critics Institute (BIRCI-Journal): Humanities and Social Sciences, 4(1), 298-309. https://doi.org/10.33258/birci.v4i1.1594

Jannah, M. I. (2021). Kajian Yuridis Kendala Pemberian Relaksasi Kredit Bagi Usaha Mikro, Kecil dan Menengah oleh Perbankan Pasca Berlakunya POJK Nomor 11 Tahun 2020 Tentang Stimulus 
Perekonomian Nasional sebagai Kebijakan Countercylical Dampak Penyebaran Corona Virus Disease .

Junaedi, D., \& Salistia, F. (2020). Dampak Pandemi Covid-19 Terhadap Pasar Modal Di Indonesia: Al-Kharaj: Jurnal Ekonomi, Kenangan \& Bisnis Syariah, 2(2), 109-138. https://doi.org/10.47467/alkharaj.v2i2.112

Kholid, M. (2018). Prinsip-Prinsip Hukum Ekonomi Syariah Dalam Undang-Undang Perbankan Syariah. Asy-Syari'ah, 20(2), 145-162. https://doi.org/10.15575/as.v20i2.3448

Mitra, S., \& Bekasi, K. (2017). PERKEMBANGAN PEMBLAYAAN MUDHARABAH PADA MASA PANDEMI COVID-19 DI INDONESIA RR. Lies Woro Susanti. 44-50.

Nainggolan, D. R. B. (2021). Perbankan Syariah di Indonesia. PT. RajaGrafindo Persada.

Ningsih, M. R., \& Mahfudz, M. S. (2020). Dampak Pandemi Covid-19 Terhadap Manajemen Industri Perbankan Syariah: Analisis Komparatif. Point, 2(1).

Sumadi, S. (2020). Menakar Dampak Fenomena Pandemi Covid-19 Terhadap Perbankan Syariah. Jurnal Hukum Ekonomi Syariah, 1, 145. https://doi.org/10.30595/jhes.v0i1.8761

Sumarni, Y. (2020). Pandemi Covid-19: Tantangan Ekonomi Dan Bisnis. Al-Intaj: Jurnal Ekonomi Dan Perbankan Syariah, 6(2), 46-58.

Susila, J. (2017). Fiduciary Dalam Produk-Produk Perbankan Syariah. Al-Abkam: Jurnal Ilmu Syariah Dan Hukum, 2(2). https://doi.org/10.22515/al-ahkam.v2i2.497

Syariah, E., Saham, S., Dan, Z. S., Hukum, J., Syariah, E., \& Ma, S. (2020). INKLUSIF : JURNAL PENGKAJLAN PENELITLAN Dini Selasi. 1, 94-113.

Tahliani, H. (2020). Tantangan Perbankan Syariah Dalam Menghadapi Pandemi COVID-19. Madani Syariah, 3(2), 92-113.

Thaha, A. F. (2020). Dampak covid-19 terhadap UMKM di Indonesia. BRAND Jurnal Ilmiah Manajemen Pemasaran, 2(1), 147-153.

Yamali, F. R., \& Putri, R. N. (2020). Dampak Covid-19 Terhadap Ekonomi Indonesia. Ekonomis: Journal of Economics and Business, 4(2), 384. https://doi.org/10.33087/ekonomis.v4i2.179

Yenti Sumarni. (2020). Pandemi Covid-19: Tantangan Ekonomi Dan Bisnis. Al Intaj: Jurnal Ekonomi Dan Perbankan Syariah, 6(2), 46-58. 